\title{
Modernist Arabic Literature and the Clash of Civilizations Discourse
}

\author{
Saddik M. Gouhar \\ United Arab Emirates University
}

\begin{abstract}
The paper explores the incorporation of western and Christian traditions, assimilated from western culture and literature in contemporary texts, written by Muslim/Arab poets and addressed to predominantly Muslim communities, in order to disrupt the clash of civilizations narrative and underline the attempt of post WWII Arab poets, led by Badr Shaker Al-Sayyab, to be engaged into transcultural dialogues with western masters particularly T.S Eliot. The paper argues that Arab poets, from ex-colonized countries, attempted to build bridges with the West by construction of a poetics that takes as its core the cultural/religious traditions of the European colonizers. Unlike writers from the ex-colonies, in Asia, Africa, Latin America, the Caribbean and the West Indies who reconstruct western texts in order to subvert them, post WWII Arab poets integrated the religious heritage of what is traditionally categorized as an alien/hostile civilization into the Arab-Islamic literary canon.
\end{abstract}

\section{The Clash of Civilizations Narrative and the September $11^{\text {th }}$ Catastrophe}

In a poem entitled "West and East", the Syrian poet, Ali Ahmad Said (Adonis) explores the historical relationship between the Arab world and the West penetrating the core of myth and tradition. Adonis alludes to the imperialist western policies which aim to subjugate the colonized people of the East:

Rupkatha Journal on Interdisciplinary Studies in Humanities

Summer Issue, Volume I, Number 1, 2009

URL of the journal: www.rupkatha.com/issue0109.php

URL of the article: www.rupkatha.com/0109modernistarabicliterature.pdf

(C) www.rupkatha.com 
There was something stretched

along histories buried path

something adorned but charged

bearing its poisoned infant of oil

with a poisonous merchant singing

his luring songs. (Khouri 1975:199)

Investigating the mutual relationship between East and West, the poet argues that the former has frequently taken its inspiration from the latter, however, in modern times things turn upside down due to ideological, political and economic conflicts. In an attempt to articulate the radical transformations resulting into tensions between East and West, Adonis denounces policies of exploitation and hegemony which provide the spark for global conflicts:

There was an East that like a child

Begged and cried for help

With the West as its unerring master

The map has been changed

The whole world is aflame

And in its ashes, East and West are gathered

In a single tomb (Khouri 1975: 199)

The Arab poet's pessimistic vision of the future of the relationship between East and West is reminiscent of Samuel Huntington's prophesy of a global war between Islam and the West. In his controversial article "The Clash of Civilizations", Huntington warns of a war that will dominate global politics characterizing Islam and the West as age old enemies and affirming that "conflict along the fault line between western and Islamic civilizations has been going on for 1300 years" (Huntington 1993: 31). To him, western ideas of individualism, liberalism, human rights, equality, liberty, the rule of law, democracy, free markets, the separation of religion and state "have little resonance in Islam" (40). 
In his book, The Clash of Civilizations and the Remaking of World Order, Huntington argues that states belonging to different civilizations are more likely to become involved in conflict with one another. According to Huntington, the basic defining characteristic of a civilization is its religion, consequently "the major civilizations in human history have been closely identified with the world's great religions"(Huntington 1993: 42). Since religion is the central indicator of a civilization, Huntington points out that inter-civilizational conflicts are usually clashes "between peoples of different religions"(Huntington 1997:253). In this context, Huntington maintains that "civilizations are the ultimate human tribes and the clash of civilizations is tribal conflict on a global scale"(Huntington 1997: 207). To Huntington, the revival of non-western religions is the most important indication of anti-western sentiments in non-western countries. Arguing that compromise in identity disputes is difficult among religiously dissimilar groups, he emphasizes the role of religion in world conflicts which surpasses the role attributed to racial or ethnic differences. According to Huntington, the post-Cold War era is characterized by global conflicts which will occur at what he calls the fault lines of the major civilizations:

It is my hypothesis that the fundamental source of conflict in this new world (the post-Cold War era) will not be primarily ideological or primarily economic. The great divisions among humankind and the dominating source of conflict will be cultural. Nation states will remain the most powerful actors in world affairs, but the principal conflicts of global politics will occur between nations and groups of different civilizations. The clash of civilizations will dominate global politics. The fault lines between civilizations will be the battle lines of the future (Huntington 1993: 22).

An assessment of Huntington's thesis lies outside the scope of this paper, however it is obvious that Huntington's argument emphasizes that the wars of ideology shaping the Cold War landscape are replaced by wars of civilizations. Central to Huntington's clash of civilization narrative is his perspective about the historic conflict between Islam and Christianity. He claims that the causes of the 
hostility between Islamic and Christian civilizations is not rooted in " transitory phenomena such as twelfth-century Christian passion or twentieth-century Muslim fundamentalism " but rather" flow from the nature of the two religions and the civilizations based on them" (Huntington1997:210). On this basis, he states that "Islam remains Islam and the West remains the West " and consequently the "fundamental conflict between these two great civilizations and ways of life will continue to define their relations in the future even as it has defined them for the past fourteen centuries"(Huntington 1997:212). Predicting an inevitable conflict between Islam and the West in the post Cold War era, Huntington insists on his thesis that "Islam's borders are bloody and so are its innards" (Huntington 1997: 258). Further, he attacks the core of the Islamic religion claiming that

...the underlying problem for the West is not Islamic fundamentalism. It is Islam, a different civilization whose people are convinced of the superiority of their culture and are obsessed with the inferiority of their power .The problem for Islam is not the CIA or the U.S. Department of Defense. It is the West, a different civilization whose people are convinced of the universality of their culture and believe that their superiority, if declining, power imposes on them the obligation to extend that culture throughout the world. These are the basic ingredients that fuel conflict between Islam and the West (Huntington 1996: 217).

In a related context, Huntington attributes the failure of Islamic communities, particularly in the Arab world, to absorb western ideals and become part of a new global order to religious differences between East and West or to what he identifies as "the inhospitable nature of Islamic culture and society" (Huntington 1997: 114). In order to support his perspective, Huntington introduces the following argument:

Wherever one looks along the perimeter o Islam, Muslims have problems living peaceably with their neighbors. The question naturally rises as to whether this pattern of late-twentieth century conflict between Muslims 
and non-Muslim groups is equally true of relations between groups from other civilizations. In fact it is not. Muslims make up about one-fifth of the world's population but in the 1990's they have been far more involved in intergroups violence than the people of any other civilization (Huntington 1996: 256).

Undoubtedly, Huntington's thesis about the reluctance of Arabo-Islamic communities to be assimilated into a globalized culture is originated in narratives of Orientalism and imperialism embedded in western imperialist policies and nineteenth-century reactionary thought which give rise to the colonial project.

Further, Huntington's argument appeared at the turn of the last century and coincided with the deconstruction of the Soviet Block in Eastern Europe and central Eurasia which paved the way for the era of globalization and the emergence of a new geopolitical reality culminating in what is called the "New World Order". Unfortunately, the new millennium started with the catastrophic events of September 11, 2001 which reinforced the voices of radical thinkers, like Huntington, Fukuyama and others who initiated an argument about the end of history predicting an Islamic holy war against the West. In other words, fears of radical Islam and the continued threat of terrorism provided impetus for the clash of civilizations hypothesis integral to western cultural discourse since the 1990's. Explicitly, the cold war attitudes of the West toward Marxism were replicated in the projection of a new global threat represented by the dangers of Islam.

\section{Toward a Dialogue with the West: Post WWII Arabic Poetry}

Regardless of Huntington's clash of civilizations discourse which magnifies the cultural and civilizational differences between the Islamic East and the Christian West, it is known that scholars and writers from different Arabo-Islamic countries, since the eighteenth century, have encouraged the establishment of an intercultural dialogue with western civilization. Even during the colonial age, prominent thinkers such as Refaa al-Tahtawi, Taha Hussein and Tawfik Al-Hakim worked toward the dismantling of the barriers separating between the Arab world and the West. They argue that in case the Arabs" are not able to establish an 
Oriental civilization, at present, they should follow the example of Turkey and simply become part of the European nations" (cited in Gohar 2002: 15). Since Arab culture has been influenced for a long time by " the Mediterranean Sea and its culture" (Hussein 1956: 4) an attempt should be made to build bridges with Europe . On this basis, Al-Tahtawi, Hussein, Al-Hakim and other Arabo-Muslim scholars defended western culture and scientific achievements calling the Arabs to be assimilated into a global civilization. Taha Hussein points out that Arab culture is not only Islamic but also has its deep roots in the Mediterranean civilizations of the Greeks and the Phoenicians (Baroot 1990: 254). Through cultural entanglements with western civilization, the Arab world, according to Hussein, would rediscover itself by restoring what the Arabs had given to the West during the golden era of Islamic civilization.

Hussein's model of cultural hybridity is adopted by major modernist poets who led the poetic movement in the Arab world in the aftermath of WWII. Engaging western thought on the epistemological and cultural paradigms, modernist Arab poets, in the post WWII era, developed a revolutionary poetics which fulfilled "the horizons of expectations" (Jauss 1982: 59) of a reading community dreaming of change and reform. Addressing a predominantly Muslim Arab audience living in societies governed by repressive regimes, the westernoriented poets of the post war generation aimed to liberate the collective Arab consciousness from the chains of a stagnant tradition. In this context, modernist Arabic poetry written by major figures like Al-Sayyab, Al-Bayati, Abdul-Sabur and others participate in bridging the cultural gap between East and West promoting an intercultural dialogue between the Arab poet/reader and his western counterpart. Hybridizing Arabic poetry with liberal western traditions and Christian narratives, modernist Arab poets aimed to alter the horizons of expectations and cultural heritage of readers who are historically isolated in backward communities and dominated by tribal traditions. Contrary to Huntington's hostile discourse about decadent Islamic communities, the academic/popular success of post WWII Arabic poetry, centered around Christian myths and integrated into the cultural traditions of the ex-colonizer, provides evidence of indigenous tendencies to be involved into dialogues with the West. 
Explicitly, the interest of Muslim/Arab readers in a poetics which glorifies the religious traditions of a culture alien to the essence of traditional Islamic thought has raised local controversy over the Arabic poetic tradition in the post WWII era. However, an exploration of the significant interaction between modernist Arabic poetry and Muslim/Arab readers which reveals the successful reception of such tradition in different Arab communities is revelation of the existence of positive attitudes toward western culture regardless of religious and historical complications. Isolating post WWII Arabic poetry from apparatuses which advocate paradigms prioritizing author and text (Iser 1978:4) and applying interpretive strategies integral to Reception Theory would also uncover a high level of "interaction between text and reader" (Holub 1984: 148).

Furthermore, the interaction between western-oriented texts and Muslim Arab readers involves a process of cultural reorientation in which the reader's "horizons of expectations" are modified to absorb new cultural paradigms transcending religious and ethnic barriers which separate between East and West. Subsequently, modernist Arabic poetry, in the post WWII era, opened new horizons for readers who have been victimized by fossilized traditions and a fundamentalist religious legacy which pulled the region backward to the Stone Age. Utilizing western cultural paradigms as liberating poetics and encouraging an inter-civilizational dialogue with the West is a manifestation of intellectual maturity of a generation of poets who followed the example of pioneering Muslim/Arab scholars like Refaa Al-Tahtawi, Taha Hussein and Tawfik Al-Hakim. Therefore, the Arab poet's call for a dialogue with the West, in the post WWII era, was not born out of a modernist immediacy but an extension of the efforts of prominent thinkers who have pursued cultural engagements with western civilization since the early colonial era.

\section{The Use of Western/Christian Narratives in Arabic Literature The Modernist Poetry of Badr Shaker Al-Sayyab}

Capturing the wounds of a nation suffering from spiritual death and political corruption, post WWII Arab poets went westward utilizing Christian and western literary heritage, particularly the poetic tradition initiated by T.S. Eliot. 
Inspired by Eliot's myths and archetypal images, poets like Al-Sayyab, AbdulSabur and Al-Bayati struggled to liberate Arabic culture and literature from fossilized traditions and stagnant heritage. Therefore, modernist Arabic poetry, in the post WWII era, written by major figures like Al-Sayyab and Al-Bayati, was characterized by an increasing use of Christian and western legends, reshaped to integrate narratives of contemporary significance in the Arab world. Explicitly, Eliot's poetry constituted the major inspiration for Arab poets who responded fervently to The Waste Land. Like Eliot, who composed the poem with the memory of WWI in his mind, they experienced tragedies of great ramifications particularly the developments of the Palestinian dilemma in 1948. Further, modernist Arab poets were fascinated in Eliot's view of tradition, his conservative religious thinking, his resourceful poetic techniques and his use of myth. Exploiting Eliot's rich traditions of poetic symbolism, Arab poets utilized western legends, Christian symbols and western archetypal figures like Prometheus and Sisyphus to articulate native issues integral to the Arab world in an era of great transformations.

As a result of integrity Eliot's theory of tradition, modernist Arab poets were able to discover their own indigenous figures attributed great importance in Arab history, like Sinbad, Antara, the pre-Islamic Bedouin warrior and Al-Hallaj, the Persian Sufi who was slaughtered by the Abassid rulers in Baghdad, in the tenth century, due to his religious beliefs. Nevertheless, unprecedented attention has been given in modernist Arabic poetry to the hardships, sacrifices and martyrdom of Jesus Christ. For example, Al-Sayyab attempts to draw explicit parallels between his own suffering under the tyrannical regime in Iraq and the torture of Christ on the cross. Discussing the use of Christian motifs in Arabic poetry, S. Moreh argues:

The favorite symbol is Christ to symbolize the poet who sacrifices himself for his country and people. Other symbols connected with the crucifixion are used, such as Christ bearing the cross which stands for the burden of the sacrifice on the way to Golgotha - the long path of suffering along which the poet has to pass. (Moreh 1976: 247). 
Obviously, the most famous symbol in modernist Arabic poetry is Jesus Christ who is frequently associated with Prophet Muhammad or Tammuz or any other deity from East and West. In spite of their Muslim background, modernist Arab poets, according to Saad Dabees, introduced Christian and medieval discourses in their poetry as a result of the literary impact of western writers particularly T.S. Eliot (Dabees 1984: 150). Being persecuted in their own countries, the Arab poets of the WWII generation felt that their efforts to change their society and its tyrannical regimes are futile. As exiles and outcasts in their own land, they express their sense of disillusionment and despair using symbols and allusions assimilated from western culture. According to Moreh, modernist Arab poets used "Christian and Biblical symbols in order to convey their own mental and physical state" (247) and reflect their psychological mood and feelings of disappointment. Therefore, in different contexts, Christ is used by Muslim Arab poets to articulate themes integral to the social and political situation in the Arab world in the post war era. In Palestinian poetry, for example, Christ is associated with the Palestinian refugees and in Iraqi poetry he is associated with the Iraqi Marxists, brutalized by Abdul Karim Qasim's regime. Furthermore, the Algerian revolutionaries, persecuted by the French occupation forces, are also associated with Christ on the cross.

Christian motifs, particularly the recurring image of Jesus Christ, a symbol of suffering and redemption, lies at the center of a poetics which pursues a mutual dialogue with western masters. Apparently, Muslim Arab poets such as AlSayyab, Al-Bayati, Abdul-Sabur, and others find some points of similarity between their political predicament and the spiritual crisis of their western forebears particularly Eliot, who experienced the tragic consequences of WWI. Recognizing the differences between the Arabic poetic tradition and its Euro-American counterpart, these poets appropriate western masterpieces such as The Waste Land, and other texts to serve national purposes in their own communities. In this context, Mohamed Said Al-Ashmawi emphasizes the existence of a cultural dialogue between modernist Arab poets and their western predecessors in which 
the Arab poets take from the West what they found appropriate for their culture and literary tastes (Al-Ashmawi 1981: 149).

As a whole, modernist Arab poets have succeeded in assimilating western and Christian cultural traditions adapting them to serve the needs of their societies in the post WWII era. For example, the frequent references and allusions, in modernist Arabic poetry, to figures such as Christ, Lazarus, Judas, Delilah, Cain, Saint Augustine and Mary Magdaline in addition to narratives of crucifixion, incarnation and redemption indicate the tendency of Muslim Arab poets to integrate western culture into the core of their poetry. Further, the excessive appropriation of western traditions involving mythic figures such as Oedipus, Ulysses, Aphrodite, Adonis, Odysseus as well as motifs dealing with fertility, resurrection and ritualistic sacrifices is an indication of a tendency on the part of Muslim Arab poets to incorporate western civilization, with its Christian and pagan aspects, to articulate indigenous purposes and local narratives. Therefore, prominent Arab critics praised Arab poets, who extensively used symbols associated with Christian teachings and theology as well as western traditions, in their attempt to explore the socio-political conditions of the Arab world in the aftermath of WWII (Al-Hawi 1980: 81).

In the modernist poetry of Al-Sayyab, Christian and western narratives are appropriated and recycled in order to express the poet's attitude toward the political situation in Iraq and the Arab world in the era of de-colonization. Utilizing Eliot's literary heritage as inter-text, Al-Sayyab explores political issues of great significance. However, some Arab critics argue against Al-Sayyab's modernist poetry because it is characterized by an excessive use of Biblical motifs and symbols derived from western culture and religions. The poet's use of Christian narratives and his treatment of themes such as sin, suffering, crucifixion and salvation led conservative critics to point out cynically that the reader of $\mathrm{Al}$ Sayyab's poetry "would undoubtedly come to the conclusion that the Muslim poet was converted into Christianity" (Al-Sadani 1988: 106). In other words, AlSayyab's attempt to work within western Christian traditions is sometimes considered as a rejection of the poet's Islamic heritage and Arab culture. Nevertheless, the poet sees his poetic initiative as an investment of his rightful 
inheritance as a human being. Therefore, whether he draws his symbolism from western sources or from the ancient near East, "it was with a universal connotation rather than a narrow local nationalistic one" (Loya 1971:198).

Being convinced that Jesus Christ belongs to all humanity and his death "symbolized the salvation of the whole human race" (Loya 1971: 197), Al-Sayyab associates himself with Christ on the cross. The bleeding wounds of the poet, who lives in exile and poverty, are supposed to bring resurrection to his barren country. Explicitly, Al-Sayyab utilizes Christian narratives, appropriated from western literature to articulate political issues integral to the poet's local community. Using Christian traditions to convey his personal tragedy as an outcast and a political exile who was forced to stay in Diaspora after being persecuted in his own country, Al-Sayyab transforms western/Biblical narratives into a poetics of protest. As a voice of opposition to the Iraqi regime in the 1950's, Al-Sayyab was frequently traced by the agents of Abdul Karim Qasim's government who considered him as a traitor due to his political views. In different poems, the Iraqi poet, isolated, exiled and cut off from his roots, identifies himself with Christ, while the Iraqi dictators are associated with Judas. The poet hopes that his split blood would lead to the redemption of his native land and the removal of the curse brought by Qasim's regime.

In his famous poem, "Christ after Crucifixion", Al-Sayyab incorporates images of suffering and salvation surrounding the crucifixion narrative identifying Christ with Iraqi political refugees, banished from their country due to his ideological views. In spite of the apparent religious overtones of the poem, it offers a vision of political transformation at a crucial stage in the history of modern Iraq. From the beginning of the poem, the Iraqi poet is transformed into a Christ figure carrying the burden of the cross. He points out that he is lonelier than Christ expressing his longing for someone to take him down from the cross, to chase away the birds of prey from his wounds and remove the crown of thorns. In spite of the great pains and suffering he passes through, the crucified poet is not yet dead: "after they brought me down I heard /the long wail of winds sweeping through the palms /and footsteps growing more distant / the wounds, 
therefore, on which they have kept me/nailed all through the evening have not killed me"(Bishai 2001: 53).

Furthermore, the analogy between Christ whose steaming blood brings fertility to the earth and the Iraqi poet whose sacrificial death would lead to the salvation of his country dominates the text of Al-Sayyab's poem: "when even the darkness grows green / warmth touches my heart/and my blood courses through its soil/my heart is water and the ear of corn/whose death is resurrection" (54). Due to his persecution under the Iraqi regime, in the 1960's, Al-Sayyab is transformed into a fertility symbol using Christian symbolism to articulate a local political narrative: "I died so that bread my be eaten in my name/ with the coming of the new season/How many lives shall I live? (54). In addition to his appropriation of Eliot's season imagery, integral to The Waste Land, to fulfill domestic purposes, Al-Sayyab utilizes the condition of Christ and his crucifixion to create a narrative of political salvation and resurrection: "I have become the future in every tomb/l have become the seed/l have become a generation/and one or some drops of my blood/flow through each heart" (55). In The Waste Land, Eliot uses seasons imagery and Christian symbolism to articulate narratives of death, fertility, salvation and resurrection integral to his aesthetic vision: "April is the cruelest month, breeding/lilacs out of the dead land, mixing/memory and desire, stirring/dull roots with spring rain/winter kept us warm, covering/earth in forgetful snow, feeding/a little life with dried tubers/summer surprises us" (Eliot 1980: 37). While Eliot used the cycle of seasons and the tale of crucifixion to express his religious perspective and moral vision, Al-Sayyab appropriates them as objective correlatives to articulate an ideological/political narrative, different from Eliot's original context.

Exploiting the ritualistic potential of the crucifixion legend as a narrative of torture, sacrifice and martyrdom, Al-Sayyab transforms Christ into a symbol of Arab nationalism and revolution against hegemony and tyrannical policies: "the eyes of suns devour my road/In which fire dreams of my crucifixion/whether made of iron or of flames/the gaze of my people is like the light/of the heavens, of memories and love/they hear my burden and moisten my cross/How small is my death and yet how great" (57). As a cry of protest against the injustice of the 
political and military establishments in Iraq in the 1950's, Al-Sayyab's poem identifies the leaders of the Iraqi government with evil figures like Judas: "I came back/Judas grew pale when he saw me/for I was his secret/he was a black shadow" (55). Depicting his confrontation with the forces of evil symbolized by Judas, Al-Sayyab speaks in the voice of Christ establishing an analogy between Christ and the Arab nationalists, persecuted and brutalized by tyrannical regimes: "I froze in his [Judas] thought/He feared death should reveal itself in his eyes/(they are a rock behind which he hid/his grave from people)/Do you come from the world of the dead?/Death comes once/could it have been false? This is what he thought when he saw me" (55). Drawing on the myth of crucifixion, AlSayyab, tortured and tyrannized during Qasim's reign, identifies his suffering and sacrifices with Christ: "Did they not crucify me yesterday?/here I am in my grave/let them come - I am in my grave/ who knows who I am? Who knows?/ and Judas's friends! Who will believe their claims? (56). The Iraqi poet's sacrifice of self for the sake of his own people repeats what Christ did for humanity. In different parts of Eliot's The Waste Land, there is a recreation of this act of sacrifice and martyrdom.

The extensive use of Christian images in Al-Sayyab's poem reflects the sweeping impact of western culture on the Muslim Arab poet [and his generation] - who attempts to introduce new pattern of symbols and myths into Arabic literature. Evoking crucifixion as a sacrificial ritual which brings salvation to the earth, Al-Sayyab becomes a Christ-figure offering his blood for the sake of his people: "here I am naked in the darkness of my tomb/yesterday I was wrapped/like suspicion, like a blossom/beneath my icy shroud/ moistening the blood red flower" (56). Depicted as a symbol of the struggle of the Iraqi nationalists who die for the sake of their cause, Christ, in Al-Sayyab's poem, is transformed from a spiritual religious figure into a revolutionary rebel resembling the poet himself. Therefore, the concluding lines of the poem give an impression of political salvation achieved through the symbolic death of the poet who believes that the Arab world is in dire need of a Christ figure to bring about the resurrection of a dead homeland : "After they had nailed me and $\mathrm{I} / \mathrm{had}$ turned my eyes towards the city/l could hardly tell the plain from the wall from the tomb/there 
was something stretching as far as the eye could see/like flowering forest/and at every turn was a cross and a grief-stricken mother/praised be God/such is the city in labor" (Bishai 2001: 57).

After great anguish and pains, the poet is able to see the Iraqi city in a state of labor which is the result of the poet's sacrificial death: "when one day I warmed the bones of children with my flesh/when I exposed my wound and dressed another/the wall between us and God was destroyed" (56). In Eliot's The Waste Land, salvation took place only after the collapse of the sinful cities and the destruction of London Bridge, symbols of western civilization: "London Bridge is falling down, falling down, falling down" (Eliot 1980: 50). At this point in the poem, Eliot's central persona is able to "set my lands in order" and map out the way for salvation after great suffering: "to cartage then I came/burning burning burning / $O$ Lord thou pluckest me out / O Lord thou pluckest / burning" (Eliot 1980: 46). Blending the pains of Christ with those of St. Augustine, Eliot expresses a splendid tale of sin, confession and resurrection rooted in his religious doctrine. Further, in Al-Sayyab's poem, the redemption of Iraq and its people is only possible after the annihilation of a tyrannical government, an epitome of injustice and brutality. Thus, the political upheaval in Iraq which inevitably culminates in the assassination of Qasim is the ultimate aim of the poet who was brutalized by the agents of the regime: "And soldiers came and reached/even my wounds and heartbeats/they came, all those who were not even dead/they came to me just as the palm tree/Laden with fruit bursts into view/when a flock of hungry birds/from a poor village lights on it" (Bishai 2001: 57). For the sake of the salvation of his cursed country, his wasteland, the Iraqi poet sacrifices his blood and the best years of his life dreaming of a better future for his homeland.

Explicitly, Al-Sayyab's poem, "Christ after Crucifixion" is part of a literary tradition constituting a transnational poetics which attempts to establish a dialogue between the Arab world and the West narrowing the cultural and civilizational gap that separate peoples on both sides. By transforming Christian narratives into a poetic mechanism serving domestic Arab perspectives, different from their original western context, Al-Sayyab provides an example of hybridity and acculturation integral to the era of globalization. In other words, the 
interaction between the Muslim Arab poet and western traditions which leads to the construction of a hybrid poetics taking as its core the religious heritage of what is traditionally categorized as an alien/colonial heritage seems to be an indication of a trans-cultural dialogue rather than a clash of civilizations. The engagement of western narratives and myths in contemporary Arabic poetry opened new horizons for religious tolerance paving the way for mutual understanding between East and West in an era of global conflicts.

\section{Works Cited}

Al-Ashmawi, M. Zaki. (1981). Azmat al-Shir fi al-Aser al-Hadith / The Crisis of Poetry in Modern Times. Fusul 4,149-167.

Al-Hawi, Eliya. (1980). Al-ramziya wa al-Siryaliya fi al-Shir al-gharbi wa alArabi/Symbolism and Surrealism in Western and Arabic Poetry. Beirut: Dar AlThaqafa,

Al-Sadani, Mostafa.(1988). Al-Taghrib fi al-Shir al-Arabi al-Mouser/Westernization in Contemporary Arabic Poetry. Alexandria: Manshaat Al-Maaref.

Baroot, M. Jamal. (1990). Qadáyá wa Shahadáth al-Hadátha: al-Qism al-Awal/Issues and Testimonies on Modernism: Part One. Cyprus: Dar Eibal.

Bishai, Nadia, Tr. Ed. (2001). Badr Sheker Al-Sayyab: Selected Poems. Cairo: General Egyptian Book Organization Press.

Dabees, Saad. (1984). Hewar Maá Qadayá al-Shir al-Musaer / Contemporary Poetry: Issues and Dialogues. Cairo: Dar Al-Fikr Al-Arabi.

Eliot T.S. (1980). The Complete Poems and Plays (1909-1950). New York: Harcourt Brace Jovanovich Publishers.

Gohar, Saddik. ( 2002), Toward a dialogue of Civilizations: The Use of Western Motifs in Modernist Arabic Poetry. Zagazig University Journal of Arts, 1-34.

Holub, Robert C. (1984). Reception Theory: A Critical Introduction. London: Methuen. Huntington, Samuel. (1993). "The Clash of Civilizations". Foreign Affairs, 22-39.

(1997). The clash of civilizations and the Remarking of World Order. New York: Simon and Schuster.

Hussein, Taha. (1956).Mustaqbal Al-Thaqafa fi Misr / The Future of Culture in Egypt, Tr. Sidney Glazer. Washington DC.: THE American Council of Learned Societies. 
Iser, Wolfgang. (1978). The Act of Reading: A Theory of Aesthetic Response. Baltimore: Johns Hopkins University Press.

Jauss, Hans Robert. (1982). Toward an Aesthetic of Reception. Brighton: Harvester.

Khouri, M and H. Algar, tr. \& ed. (1974). An Anthology of Modern Arabic Poetry. Berkeley: University of California Press.

Loya, Arieh. ( 1971). Al-Sayyab and the Influence of T.S. Eliot. The Muslim World LXI 3 , 187-201.

Moreh,S. (1976). Modern Arabic Poetry 1800-1970. Leiden: E.J. Brill.

Writer: Saddik M. Gouhar, Associate Professor, United Arab Emirates University.Email:s.gohor@uaeu.ac.ae 